\title{
米 \\ O MAPA, OS MAPAS. PROPOSTAS METODOLÓGICAS PARA ABORDAR A PLURALIDADE E A INSTABILIDADE DA IMAGEM CARTOGRÁFICA*
}

- CARLA LOIS**

Resumo: Enquanto "mapa" é toda "representação gráfica que facilita o conhecimento espacial de coisas, conceitos, condições, processos ou eventos que concernem ao mundo humano", o termo "mapa" refere-se a muitas imagens diferentes, que usam diversas técnicas e suportes, apelam à linguagens visuais muito heterogêneas, convenções gráficas que tem variado ao longo do tempo, etc. Este trabalho propõe duas categorias metodológicas para abordar a pluralidade da imagem cartográfica sem renunciar a essa definição ampla e inclusiva. A primeira é a noção de gênero cartográfico, que permite agrupar e classificar mapas que compartilham chaves temáticas, estilísticas, técnicas e/ou composicionais. A segunda é a noção de série porque a montagem de uma série cria chaves de leitura e de interpretação e, consequentemente, um mesmo mapa não comunica o mesmo em duas séries diferentes. As potencialidades e as limitações dessa proposta metodológica serão discutidas adiante baseadas em exemplos.

Palavras chave: Gênero cartográfico; Série; Metodologia; Cultura visual; Mapa 
Introdução. Por uma metodologia do visual para os mapas

A partir do termo "mapa" pode-se designar uma multiplicidade de imagens muito diferentes, que usam diversas técnicas e suportes, apelam a linguagens visuais muito heterogêneas, convenções gráficas que tem variado ao longo do tempo, etc. Alguns autores têm escolhido lidar com essa variedade, restringindo a definição de mapa. Nós, por outro lado, assumimos que mapa é toda "representação gráfica que facilita o conhecimento espacial de coisas, conceitos, condições, processos ou eventos que concernem ao mundo humano." ${ }^{1}$ É uma definição ampla, flexível, inclusiva que nos permite considerar "mapa" coisas tão diferentes como um esboço à mão livre, uma folha topográfica, uma obra de arte, entre outras. Mas, não podemos negar que essa postura, embora seja muito rica a partir do ponto de vista conceitual e teórico acarreta algumas dificuldades de método que saltam à vista no momento da análise dos mapas ou no uso de cartografias como fontes na investigação social.

A rigor, não é uma deficiência que afeta exclusivamente a análise de mapas. Mesmo que tenha se tornado comum afirmar que vivemos em uma época eminentemente visual e "ocularcêntrica" marcada pela ubiquidade das imagens, pelos incessantes estímulos visuais e a multiplicidade de suportes que permitem a circulação de imagens - os especialistas coincidem em afirmar que esse incremento (aparente ou real) de imagens não tem sido acompanhado por uma reflexão metodológica suficientemente sofisticada e sólida. Talvez com a única exceção das disciplinas que tem uma forte tradição no tratamento de imagens, como a história da arte ou a estética, a incorporação dos registros visuais nos estudos culturais parece dominada por explorações intuitivas e comentários superficiais que passeiam sobre as imagens sem alcançar seus desdobramentos.

Nesse sentido, o ditado popular "uma imagem vale mais que mil palavras" falaria menos de sua eloquência que da impossibilidade da linguagem para expressar a imagem ou, como disse Mitchell, "a impossibilidade de uma metalinguagem estrita, uma representação de segunda ordem que está à margem de seu objetivo de primeira ordem" (MITCHELL, 1994: 79).

Entre os geógrafos se destacam alguns esforços para clarificar os desafios metodológicos que implica o tratamento de materiais visuais. Gillian Rose, em seu recente livro Visual Methodologies. An Introduction to researching with Visual Materials, aporta alguns pontos interessantes: por um lado, demonstra não somente que as imagens são polissêmicas, mas também que uma mesma imagem pode comunicar ideias contraditórias; por outro lado, enfatiza o fato de que uma mesma imagem pode gerar diferentes reações e significados em distintas audiências. Então, propõe-se uma série de perguntas focadas em três dimensões do visual: o processo de produção da imagem, a imagem em si e as múltiplas audiências que interagem com essa 
imagem. Como resultado, Rose defende a formulação de novos métodos críticos para análise do visual que apostem no hibridismo e na combinação ad hoc de diferentes tradições mais que a busca de uma fórmula rígida que funcione como receita para todas as imagens.

Em sintonia com essas observações, a profunda revisão acerca da natureza cultural das imagens cartográficas que está revolucionando os estudos de história da cartografia ainda não dispõe de propostas metodológicas sistemáticas que permitam examinar os mapas para além das questões de precisão das localizações, do nível informativo ou da pertinência da eleição das variáveis visuais.

Nesta apresentação procuraremos fazer um aporte nessa direção. Centraremo-nos em duas propostas metodológicas que visam oferecer categorias para trabalhar a pluralidade do mapa: evitar generalizações atribuídas ao "mapa" no singular e precisar o tratamento do mapa com uma imagemobjeto complexa, variável e instável que, contudo, pode ser abordada rigorosamente.

A primeira é a noção de gênero cartográfico inspirada no conceito bajtiniano de gênero literário e adaptada à graficidade do mapa. A categoria analítica de gênero permite agrupar e classificar mapas que compartilham chaves temáticas, estilísticas, técnicas e/ou composicionais. Sua maior utilidade radica em orientar as perguntas possíveis e evitar anacronismos ou abordagens estéreis.

A segunda é a noção de série, que já tem sido trabalhada na história da arte (Warburg) e na filosofia (DidiHuberman). A presunção básica é que a montagem de uma série cria chaves de leitura e interpretação e que, portanto, um mesmo mapa não comunica o mesmo se é posto em duas séries diferentes. 0 modo em que construímos uma série afeta os sentidos do conjunto das imagens tanto como os sentidos que comunicam cada uma delas e os aspectos visíveis e invisíveis nos modos de leitura que propõe a série.

Com uma ampla quantidade de exemplos se discutirão as potencialidades e as limitações destas propostas metodológicas.

\section{Pensar o mapa no plural}

Em 1973, a Internacional Cartographic Association ${ }^{2}$ definia que o mapa é uma representação da relação de recursos materiais ou abstratos da superfície terrestre ou de um corpo celeste, geralmente feito em escala e desenhado sobre um plano. ${ }^{3}$ Essa definição se fez muito popular e contribuiu para instalar o sentido comum: a convicção de que o mapa é uma re-apresentação da superfície terrestre ou de uma parte dela. É uma definição simples. Talvez essa simplicidade é o que explica o fato dessa concepção ter-se tornado tão arraigada que ainda persiste e torna nebulosa as implicações epistemológicas inerentes ao enfoque que consagra as operações técnicas como método infalível (embora perfectível, na medida em que se melhorem as técnicas) para reduzir o 
real e lograr capturá-lo em um plano. Seguramente o gosto e a ansiedade que se manifestam em nossas sociedades por dispor de imagens científicas que nos mostrem o mundo "tal como ele é" contribui muito para reforçar a crença nas promessas de mimeses que sugere a definição da ICA.

Não obstante, essas observações ou críticas requerem esclarecimento porque o problema que apresenta essa forma de conceber um mapa não radica na definição em si. Mais ainda: o problema não está no fato de tal definição estar equivocada, mas por ser demasiada limitada e reducionista.

Em certo sentido, essa concepção de mapa assemelha-se com a transparência que se atribui à fotografia. A discussão sobre essa aparente neutralidade da fotografia tem uma longa tradição que não ficou restrita aos debates entre fotógrafos e especialistas em fotografia, mas que também incluiu reflexões e ensaios de alguns dos mais renomados intelectuais, como Roland Barthes, Susan Sontag, Walter Benjamin, entre outros. Muitos deles abordaram questões como a crítica à ilusão do realismo, ao olhar ingênuo que pousa passivo sobre a imagem e ao talismã da técnica como garantia de objetividade. Quer dizer, problemáticas afins que detectamos como obstáculos epistemológicos para o tratamento crítico dos mapas como objetos culturais.

No caso da fotografia, a ilusão do realismo está ancorada nos processos físico-químicos que fazem com que a luz deixe um traço visível em materiais fotossensíveis, de modo que enquanto produz mecanicamente imagens, lhe é atribuído o poder de retratar a realidade. No caso dos mapas, se apela à ciência e aos procedimentos matemáticos necessários para transformar o real em uma miniatura que se encaixe em um papel. "Na fotografia não se reproduz nada, se produz como em uma fábrica", dizia François Soulages: "há um processo de produção. Portanto, a fotografia não é da mesma ordem, mas de outra. E, contudo, se seguiu e se segue fotografando como se esta crítica do realismo não tivesse sido feita. 0 que anima esse "como se"? 0 que se oculta por detrás?" ${ }^{4}$. Pois, o ponto crucial dessa proposta é que nos mapas tampouco nada é reproduzido.

Contudo, se temos em conta que em plena era digital a maioria das pessoas interveio, alterando ou modificando uma fotografia ao menos uma vez na vida e, ainda assim, a fotografia segue conservando uma aura realista praticamente indestrutível, sendo a prova mais elementar o senso comum, não deveria surpreendermo-nos que também persista ferrenhamente a noção de mapa como instrumento neutro e científico ${ }^{5}$.

As concepções 'realistas' sobre a natureza do mapa que se nutrem dessa definição da ICA são tão potentes que para bani-las ou ao menos para pô-las seriamente em questão não tem sido alcançada com a criação de novas definições. De fato, tem quase trinta anos que Brian Harley e David Woodward cunharam a ideia de que o mapa é toda representação gráfica que facilita o conhecimento espacial de coisas, conceitos, condições, processos ou 
eventos que concernem ao mundo humano ${ }^{6}$. Todavia, ainda continua sendo tediosamente necessário afirmar que às vezes os mapas "mentem" (Monmonier) ou que não tem nenhum vínculo com as "geografias reais" e que as "geografias pessoais" vêm acompanhadas por seus próprios "mapas da imaginação" (Katherine Harmon).

Nosso ponto de partida recupera essa definição de Harley e Woodward para afirmar que mesmo que as imagens sejam muito diferentes entre si podem ser, todas elas, consideradas legitimamente "mapas", seja tratando-se de uma folha topográfica, de uma imagem do Google Maps ou do mapa de um lugar imaginário. É evidente que a diferença entre elas merece distintos tratamentos e, sobretudo conceituações específicas para cada caso, o que nos leva necessariamente a falar de mapas no plural.

A primeira consequência de adotar uma concepção ampla para pensar o objeto mapa é a abertura de uma insuspeitável constelação de imagens heterogêneas que são capazes de reclamar para si mesmas o status cartográfico independentemente do seu grau de "cientificidade". Assim, podemos chamar "mapa" um croqui à mão livre feito por nós mesmos para marcar o itinerário entre a casa e o trabalho. Inclusive, podemos declarar "mapa" a obras artísticas: o quadro Map do artista americano Jasper Johns pede ao espectador, a partir do modesto, mas certeiro título que simplesmente anuncia "mapa" que encontre nesses traços de aparência caprichada um mapa. Se o espectador fica alguns segundos a mais diante da obra terá tempo suficiente para reconhecer os nomes dos estados dos Estados Unidos e dos oceanos. Inclusive, aguçando um pouco mais a vista, poderá advertir que a orientação das pinceladas sugere as formas de cada um dos estados. É certo que sua estética contradiz um dos princípios que se demanda aos mapas científicos; isto é, a precisão. Não obstante, Johns nos apresenta um mapa. E essa imagem não é "menos" mapa do que outras imagens cartográficas. É, sem dúvida, uma imagem cartográfica menos convencional e mais criativa do território estadunidense, mas que ainda assim é reconhecível porque, apesar da distância que existe entre essa imagem e o mapalogotipo ${ }^{7}$ oficial dos Estados Unidos que ilustra as paredes das aulas escolares, se inscreve dentro de certos limites de execução que garantem o reconhecimento daquele mapa arquetípico que evoca e recria. 0 mapa de Johns se inscreve dentro de certos "limites" que demarcam um terreno onde cabem muitas possibilidades, mas fora dos quais a imagem deixaria de ser reconhecível. Ademais, o artista nos orienta com determinação: oferece-nos essa ajuda inicial no título que é a chave de todo o processo de reconhecimento. Convenhamos que se a obra se chamasse "Cores primárias", nosso olhar se dirigiria a identificar o vermelho, o azul e o amarelo em vez de averiguar traços cartográficos. Todavia, esses topônimos levam a compor uma ordem e tecer as relações espaciais que permitem restituir uma imagem dos Estados Unidos que é de fato cartográfica ${ }^{8}$. 
Outro caso de mapa artístico igualmente célebre, embora provavelmente muito mais familiar para as audiências latinoamericanas é o mapa invertido da América do Sul que o artista uruguaio Torres García criou e recriou em várias oportunidades nas décadas de 1930 e 1940. E, neste caso, Torres García representa seu posicionamento político apostando "contra o mapa" (DE DIEGO OTERO, 2010): inverte o sentido tradicionalmente utilizado nas representações cartográficas que direciona o Norte na parte superior do mapa e proclama que "nosso Norte está no Sul". De contornos simples, não deixa de incluir as linhas imaginárias do Equador para enfatizar a questão da inversão dos hemisférios.

Esses dois exemplos de mapas artísticos são trazidos aqui para ajudar-nos a questionar o que tomamos por consumado quando escutamos ou dizemos "mapa" e para incorporar que a ideia de "mapa" no singular é tão abstrata e polivalente como a do "texto", de maneira tal que requer certas precisões conceituais para poder pensar métodos de abordagem. E, como se essa fissura que se abre com os mapas artísticos não fora suficiente para demonstrar a necessidade de repensar o mapa no plural, como tratar aqueles casos em que a palavra "mapa" é usada metaforicamente? Por exemplo: mapa conceitual, mapa de DNA, mapa da situação, mapa de site... São ou não são mapas? Em certo sentido, sim, o são, no entanto, todos estes usos fazem prevalecer a afirmação de relações espaciais ${ }^{9}$. É possível fazer um uso metafórico do termo "mapa" para casos como os que acabamos de mencionar porque podemos ver que neles se recuperam duas propriedades que parecem inerentes a toda imagem cartográfica: a inscrição gráfica de relações espaciais e do pensamento analógico.

É evidente que se abre um universo complexo ante nossos olhos, uma vez que essa diversidade e pluralidade abrange múltiplas formas de funcionamento: nem todas essas imagens cartográficas comunicam da mesma maneira, nem se leem igual, nem resultam igualmente persuasivas.

É possível pensar estratégias de método para que possamos trabalhar com as imagens cartográficas abandonando o pantanoso terreno das interpretações intuitivas sem renunciar a sua pluralidade nem a sua complexidade.

\section{Os gêneros cartográficos}

A ideia de que universo de mapas é amplo e variado não é uma novidade. Existiram e existem propostas de classificação para organizá-lo. A mais conhecida entre os geógrafos é a que distingue entre plano, mapa e carta segundo a escala. Convencionalmente denomina-se "plano" as representações de escalas maiores do que 1: 50.000 (como um plano urbano); "mapa" as representações cujas escalas vão entre 1: 50.000 e 1:500.000 (como folha topográfica) e "carta" aquelas maiores que 1:500.000 (como um planisfério). Em rigor, a escala, mais que uma questão de tamanho é um dispositivo de visualização: certos fenômenos são 
visíveis em certa escala e ficam totalmente invisíveis em outras. Contudo, não podemos queixar-nos de que frequentemente se confunda escala com tamanho enquanto se segue repetindo sem muita reflexão essa classificação ordenada, que acaba por parecer uma mera distinção terminológica já que, assim enunciadas, aparentemente essas categorias não implicam em operações distintas nem nenhuma diferença conceitual além dos limiares numéricos definidos pelo denominador da escala.

Outra classificação histórica se baseia na bifurcação técnica, profissional e gráfica que desde o século XIX, tendeu à separação definitiva da cartografia temática e da cartografia topográfica.

Nas palavras do geógrafo francês Gilles Palsky, “o século XIX foi o século do paradigma da exatidão topográfica e também da 'divergência de caminhos' entre os mapas topográficos e as cartas temáticas. A carta topográfica não podia responder a todas as curiosidades sem prejuízo na sua eficácia de comunicação. Foi assim que a comissão de topografia de 1828, encarregada de adotar os signos convencionais da carta do Estado Maior, eliminou símbolos de mineralogia e geologia porque estimava que só uma carta especial podia expressar corretamente a natureza do subsolo. Em outros termos: estabelecer limites estritos ao inventário do mapa geral é afirmar a separação entre o topográfico e o temático. Diversos mapas especiais vinham sendo realizados desde o século XVII, mas - no quadro de uma geografia de posições, aplicada a localizar e qualificar os objetos visíveis - seu lugar continuava marginal. Existiam cartas temáticas pioneiras elaboradas antes de 1800, nas quais figuravam, por exemplo, os ventos, as correntes e o magnetismo. Contudo, foi só no século XIX, que se definiu o essencial do desenvolvimento dessa cartografia, em consonância com a tendência de estruturação de novos campos de conhecimentos"10.

$$
\text { Certamente a cartografia }
$$
topográfica e a cartografia temática constituem campos de trabalho diferentes e é uma primeira classificação pertinente. Mas, isso não resolve a questão metodológica que temos levantado aqui; por um lado, porque a variedade dos mapas temáticos é tão ampla e diversa que dificilmente podemos encontrar um critério válido que permita agrupá-las. Por outro lado, porque existe um conjunto crescente de mapas "fora da cartografia"; quer dizer, imagens cartográficas que combinam certa estética cartográfica, mas não necessariamente recorrem a todas suas convenções, suas linguagens e seus códigos de representação. Provavelmente, o exemplo mais caro disso sejam os mapas artísticos, conforme os mencionados anteriormente. Todavia, veremos que há muito mais.

Para domesticar o caos aparente desse universo tão diverso, complexo e variado que se configura quando pensamos no mapa plural uma opção metodológica consiste em conceitualizar e organizar as imagens segundo gêneros cartográficos. Se trata de uma adaptação do uso que se faz desta categoria na crítica literária e, especialmente, na concepção bajtiniana do termo. A 
categoria de gênero literário assume que as construções da linguagem podem agrupar-se segundo tipos relativamente estáveis, enquanto o conteúdo temático, ao estilo linguístico (a seleção de recursos léxicos, fraseológicos e gramaticais do idioma) e a construção compositiva (BAJTIN, 2011:11) ${ }^{11}$.

Assim, por exemplo, os mapas topográficos, os mapas de caricatura, os mapas artísticos e os mapas meteorológicos compartilham uma série de elementos com a cartografia físicopolítica, contudo cada um desses gêneros cartográficos se comunica com um estilo, uma composição, uma arquitetura visual próprias.

Então, para além dos mapas artísticos, que outros gêneros cartográficos podemos indicar? Para abrir a proposta, enunciaremos alguns que não apresentam maiores dificuldades para ser identificados: os mapas turísticos, os mapas meteorológicos, os mapas de rotas, os mapas políticos... e a lista pode ser quase infinita. 0 gênero não é uma categoria fechada que encerra a identidade da imagem. Pelo contrário, o mesmo mapa pode formar parte de diversos gêneros. Ao mesmo tempo, essa relocalização do mapa em um gênero ou outro não é inócua: repercutirá nas perguntas que se pode fazer ao material empírico, assim como à seleção de corpus com os quais tais mapas possam dialogar.

Em qualquer caso, o ponto chave passa por evitar as aproximações intuitivas ou julgar todo mapa segundo a "precisão da informação que oferece" e, em troca, por saber, conhecer, criar e estabelecer os elos que unem os mapas que compartilham um gênero. Esses elos não necessariamente provêm da lógica interna do mapa e nem sempre vem dados por ele. Temos naturalizado que certos mapas são de um gênero frequentemente definido pelo tema (por exemplo, mapas de população, mapas de fluxos de divisas, etc.) Não obstante, é necessário frisar que há gêneros que se definem mais por sua estética que por seu tema.

Chegando a este ponto, pode parecer óbvio, mas é necessário dizer: a classificação de gêneros cartográficos surge no mesmo processo de ordenação do material e da investigação. Como toda ordenação, tem um objetivo específico e, consequentemente, não se trata de alcançar uma taxonomia de validez universal. Cada vez que montamos uma série, montamos um novo mundo.

Certos tipos de séries tornaramse canônicas e as temos internalizado como forma de agrupar os mapas; por exemplo a coleção de mapas de um mesmo lugar com diferentes escalas ou também o agrupamento de planos de uma mesma cidade ao longo do século. Contudo, esses critérios geográficos e temporais, usados recorrentemente como os fios que tecem séries para as quais estamos mais ou menos bem preparados para ler e comparar, podem coexistir com outros que criam laços inesperados entre tais imagens.

\section{Montar uma série, montar um mundo}

Esse diálogo entre as imagens cartográficas (sejam do mesmo gênero ou não) e mesmo entre as imagens cartográficas e outras de diversas 
naturezas é uma operação que consiste em criar séries.

A montagem de uma série consiste em pôr umas imagens próximas às outras, compartilhando um mesmo painel, uma mesma página de livro ou o mesmo dispositivo em Power Point. Essa composição física não é um mero ordenamento, mas uma especialização das imagens que produz sentidos que articulam a especificidade de cada imagem com o vínculo que se gera na observação simultânea dessa série.

Sem dúvida, em toda conceituação da ideia de série a referência inevitável é o Atlas Mnemosyme de Aby Warburg. 0 experimento warburgiano consistiu em reunir imagens e organizá-las em painéis que incluíam discretas etiquetas que identificavam as imagens. Sobre o trabalho de Aby Warburg, o filósofo francês Didi-Huberman dizia: "se tratava de suscitar a aparição através do encontro de três imagens diferentes, de certas 'relações íntimas e secretas', certas 'correspondências' capazes de oferecer um conhecimento transversal dessa inesgotável complexidade histórica (a árvore genealógica), geográfica (o mapa) e imaginária (os animais do Zodíaco) (DIDI-HUBERMAN, 2010:19).

Em ocasião da abertura da mostra "Atlas, como carregar o mundo nas costas?", Didi-Huberman retomou a proposta inconclusa dessa ciência sem nome que sonhava Warburg. Escolheu o termo "atlas" para definir a montagem que supõe uma série e, ao evocar a mitologia grega do Deus que teve que carregar o céu e a Terra sobre suas costas, permite vislumbrar que essas imagens montadas na mostra também, à sua maneira, carregam o mundo nas costas.

Mas, a verdadeira novidade é o dinamismo que lhe dá essa ideia: "O Atlas, todavia, se guia basicamente por deslocamentos e princípios provisórios, o que podem suscitar em inesgotáveis novas relações - ainda mais numerosas que suas conclusões - entre outras coisas ou palavras que em princípio não pareciam agrupáveis (DIDI-HUBERMAN, 2010: 16).

0 atlas não é entendido como uma forma acabada, tal como se assume em sua acepção mais conhecida, que refere a um livro de mapas já impressos. 0 atlas é muito mais, é uma mesa de trabalho: "na época estruturalista, falava-se muito do quadro como 'superfície de inscrição': na verdade, institui sua autoridade através de uma inscrição duradoura, um encerramento espacial, uma verticalidade que nos domina a partir do muro que sustenta, uma permanência temporal de objeto cultural. 0 quadro consistiria, portanto, na inscrição de uma obra (a grandíssima opera de pittore, escrevia Albert) que pretende ser definitiva ante a história. A mesa é mero suporte de um trabalho que sempre se pode corrigir, modificar, quando não, começar de novo" (DIDI-HUBERMAN, 2010: 18).

Essa possibilidade de corrigir, modificar e começar de novo que destaca Didi-Huberman não é outra coisa senão a possibilidade de rearmar a série, de redefinir os gêneros, de reclassificar a imagem cartográfica e de restabelecer os vínculos entre elas, outras imagens ou outros textos. É também a marca da instabilidade da imagem cartográfica, que devemos recuperar com um ponto 
positivo. No lugar de associar a instabilidade à incerteza e à vertigem, renunciar as certezas de definições reducionistas e aceitar essa flexibilidade do objeto abre um prisma infinito de possibilidades para analisar como participam os mapas em nossas experiências e concepções sobre o espaço, a história, a sociedade e o mundo.

A série, longe de ser uma mera acumulação de objetos singulares, é a singularidade de uma combinação possível entre muitas outras. Em outro trabalho, Georges Didi-Huberman analisa a obra "Nés", de Philippe Bazin, que consiste em dezoito imagens de uma série de trinta e seis retratos, fotografias de $45 \times 45$. Bazin disse de sua própria obra: "Sempre trabalho com série porque fotografar uma grande quantidade de pessoas me permite deixar surgir sua singularidade mais inevitável"12. E, Didi-Huberman (2014: 52), destaca essa combinação série singularidade afirmando que se "reúne uma grande quantidade de singularidades dispostas em séries (...). Não é, pois, o mesmo rosto, mas a comunidade de rostos a que nesse trabalho pode remeter-se a um possível retrato da humanidade. Esse retrato só existe, por conseguinte, ao constituir-se como retrato de grupo".

No processo de investigação (geográfica, histórica, social) aplicamos certa "vigilância epistemológica", diria Bourdieu, para explicitar os critérios que nos levam a compor determinadas mesas. Aí é onde parece particularmente útil pensar a noção de gênero cartográfico como princípio ordenador e, a partir daí o desafio passa por fazer da série em questão um objeto significativo.
A premissa norteadora dessa proposta metodológica é que os mesmos mapas dispostos em séries diferentes variam seus sentidos, a forma em que são questionados, lidos e julgados. Nas palavras de Berger, "o modo em que uma imagem segue a outra em um filme, sua sucessão, constrói um argumento que resulta irreversível" (2012:34). Ilustraremos isso a partir de três séries distintas.

\section{Exercícios. Os mesmos mapas em distintas séries}

Nesta seção, faremos o exercício de colocar em ação as categorias desenvolvidas nos itens anteriores, com a intenção de mostrar como alguns mapas repetidos em diversas séries se prestam a ser observados e interpretados de maneiras diferentes em cada caso.

\section{Série 1.1 Mapas de redes de metrô}

Na série 1.1 (Figuras 1, 2, 3, 4) montamos um atlas ao qual poderíamos intitular "mapas de redes de metrô". Embora os planos sejam muito diferentes entre si, eles formam uma série clássica, já que compartilham o tema base que se enuncia no título dado à série.

A imagem 1.1 a (Figura 1) é o célebre mapa do metrô de Londres desenhado por Harry Beck em 1931 e que, apesar das resistências geradas a princípio por causa da forte marca de abstração no desenho que não corresponde literalmente ao traçado 


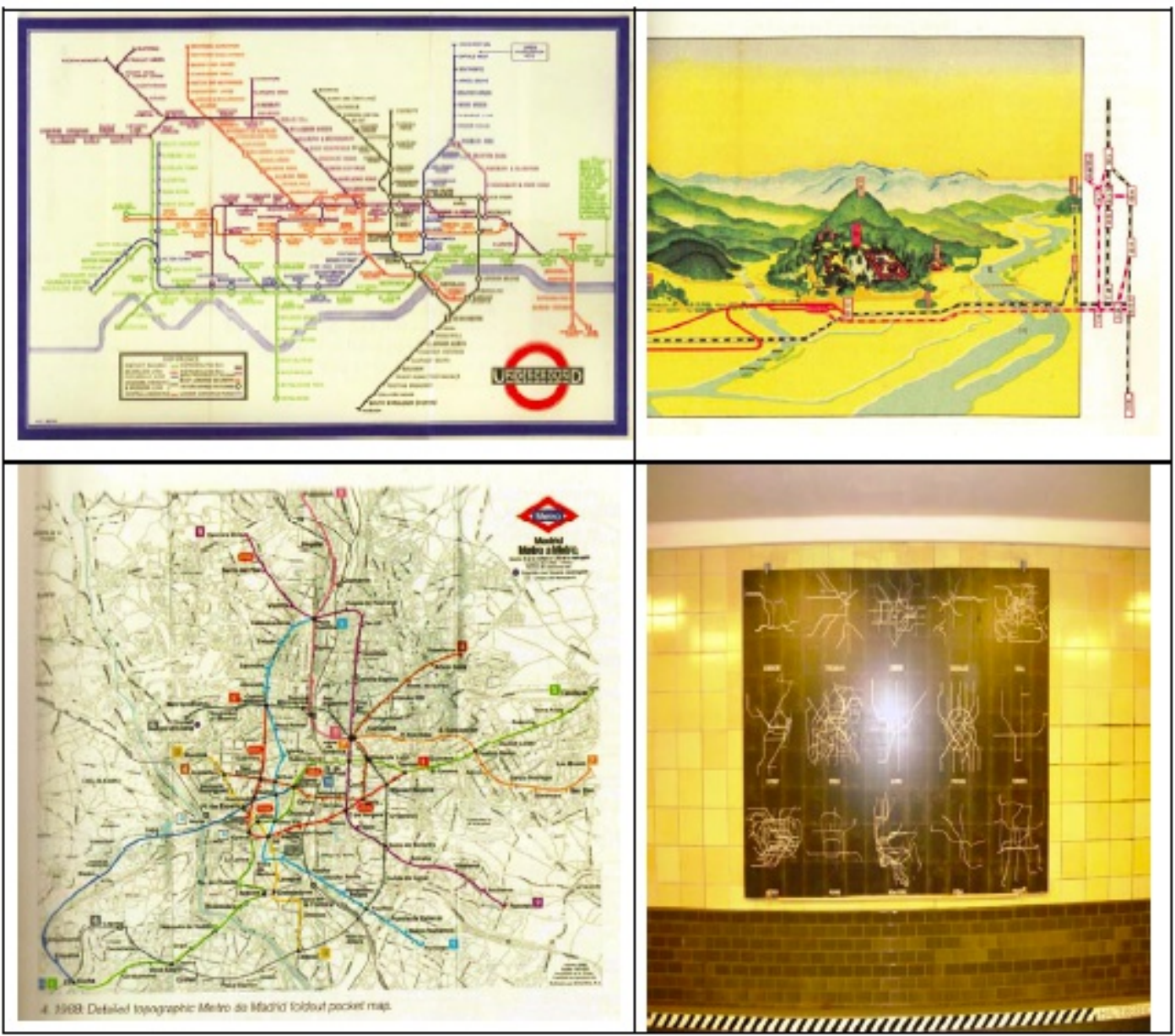

Figura 3 (Imagem 1.1 c)

Figura 4 (Imagem $1.1 \mathrm{~d}$ )

Fonte: Fotografias próprias

analógico real da rede ${ }^{13}$, hoje é usado como um esquema base para o traçado de quase todas as redes de metrô do mundo ${ }^{14}$. O mapa aposta em otimizar a legitimidade usando linhas coloridas que se cruzam em ângulos de 45 a 90 graus. Comparemos a legibilidade e os modos de uso entre este mapa e a imagem $1.1 \mathrm{c}$ (Figura 3) que é o mapa do metrô que utilizavam os usuários da rede de Madrid em 1988, antes de o Conselho Municipal adotar o esquema que segue os preceitos definidos por Beck para o sistema londrino.

A imagem $1.1 \mathrm{~b}$ (Figura 2), mostra a rede ferroviária e rodoviária tirada de um guia de viagem japonesa ${ }^{15}$. Chama atenção por combinar múltiplas perspectivas (incluindo a representação pictórica da paisagem a partir de um ângulo oblíquo, ao "voo de pássaro"). Por um lado, as convenções pictóricas utilizadas não nos são familiares ou 
facilmente comparáveis aos mapas anteriormente mencionados. No entanto, não duvidaríamos que os três mapas cumprem funções semelhantes e que, portanto, podem compartilhar o mesmo espaço numa série. Ao mesmo tempo, a estranheza que geram esses símbolos ilegíveis nos faz reparar a existência dos nomes (as estações de metrô) que lhes dão todo potencial de uso para os outros mapas do metrô.

$\mathrm{Na}$ imagem $1.1 \mathrm{~d}$ (Figura 4), sobre um painel de azulejos na Estação Bernauer Straße de Berlim, vemos uma combinação de esboços de redes de metrô de algumas grandes cidades do mundo. Os esboços estão redesenhados a partir da estrutura que emerge dos planos de metrô das cidades. Não têm referências nem marcas de suas especificidades locais, com exceção do nome da cidade em que se encontram. De um ponto de vista gráfico, estão todos desenhados com linhas brancas e não incluem nenhuma convenção de cores, nomes ou signos (de acessibilidade, combinação ou correspondência de setores fechados por obras) que cada um desses mapas tem em seus respectivos originais. Essa homogeneização da linguagem esquemática e a coexistência no painel, predispõe ao observador a comparar as formas e a densidade das redes de metrô de algumas grandes cidades do mundo.

Em suma, a série 1.1 articula quatro mapas de redes de metrô que usam diferentes linguagens gráficas, têm diferentes tamanhos, estão dispostas em suportes de diferente natureza e que têm um alcance variado em suas respectivas audiências. No entanto, podem ser agrupados sob o gênero "mapas de metrô" e dados a comentários analíticos e comparativos que surgem do olhar simultâneo destes quatro itens.

Em outras palavras, a série tem uma identidade comum que recai sobre o tema que compartilham, que estão para além das diferenças estilísticas e materiais.

\section{Série 1.2 Mapas que compartilham uma linguagem cartográfica específica para representar temas incongruentes entre $s i$}

Se observarmos a série 1.2 (Figuras 5, 6, 7, 8) com certo distanciamento, aparecem todas as variações de um mesmo mapa.

Mas se olhamos mais de perto, surgem diferenças-chave. Com efeito, a imagem 1.2 a (Figura 5) corresponde à imagem da série 1.1; é o mapa do metrô londrino desenhado por Beck em 1931. Mas agora, ao invés de dialogar com outros mapas de metrô, aparece como modelo de linguagem gráfica e é adotado para representar outros temas que nada tem a ver com o transporte urbano subterrâneo: na imagem 1.2 b (Figura 6) estão representados os vinhos da França (cada linha/cor representa uma região vitivinícola); na imagem 1.2 c (Figura 7) há um mapa de filmes e em cada linha/cor representa um gênero fílmico; e a imagem $1.2 \mathrm{~d}$ (Figura 8) as linhas das redes de metrô apenas servem para configurar as letras do abecedário em uma folha didática para crianças. 


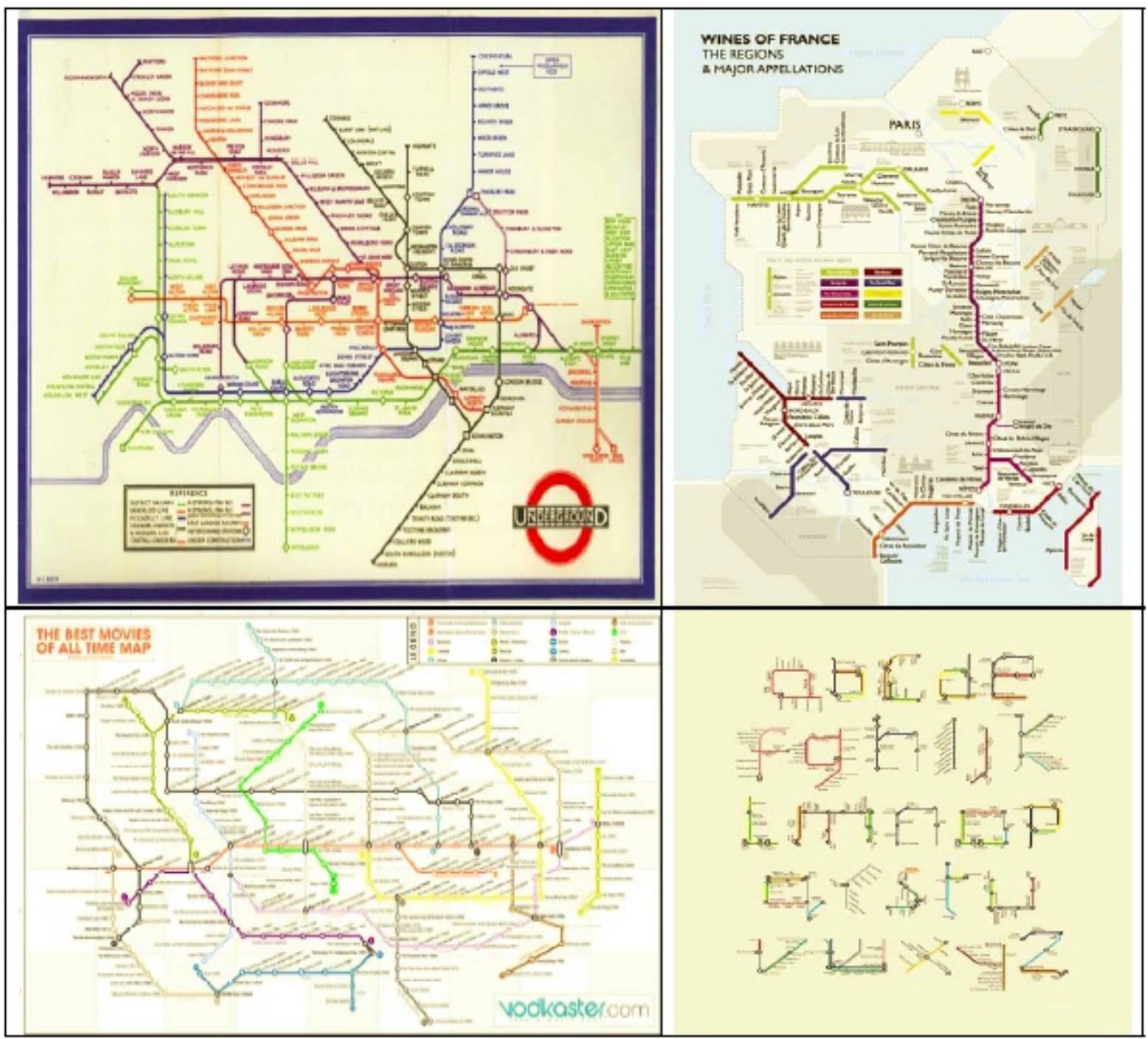

Figura 7 (Imagem 1.2 c)

Figura 8 (Imagem $1.2 \mathrm{~d}$ )

Nessa série, o denominador comum que entrelaça as imagens é a linguagem gráfica, claramente identificado com um gênero cartográfico e aplicado a outros temas que não sonham em ser mapeados. Os laços que predominam nessa série são os estéticos, ao mesmo tempo que sancionam a eficácia do mapa beckiano já naturalizado no senso comum. 
Série 1.3 Mapas na via pública

Na série 1.3 (Figuras 9, 10, 11, 12), reunimos mapas de diversos gêneros e aspectos: o mapa do estado de Nova Iorque, uma pintura de um globo terrestre, o mapa da ilha mediterrânea Palma de Mallorca e a composição de esboços de redes de transporte subterrâneo no metrô de Berlim. Os critérios de entrelaçamento dos quatro itens que formam esta série é a materialidade dos mapas, portanto, selecionamos aqueles que estão pintados ou confeccionados com mosaicos na via pública.
A imagem 1.3 d (Figura 12) com a montagem da morfologia das redes de metrô de algumas cidades do mundo, era a imagem $1.1 \mathrm{~d}$ da outra série. Mas, enquanto na outra série ela coabitava com outros mapas de transporte, nesta série se relaciona com outras imagens a partir de sua materialidade e localização: os mosaicos e azulejos que configuram mapas em vias públicas.

Em sintonia com ela, a imagem 1.3 a (Figura 9) mostra o mapa do estado de Nova Iorque armado com pastilhas na parede de um departamento de polícia na Broadway, localizada em uma rota

Figura 9 (Imagem 1.3 a)

Figura 10 (Imagem $1.3 \mathrm{~b}$ )

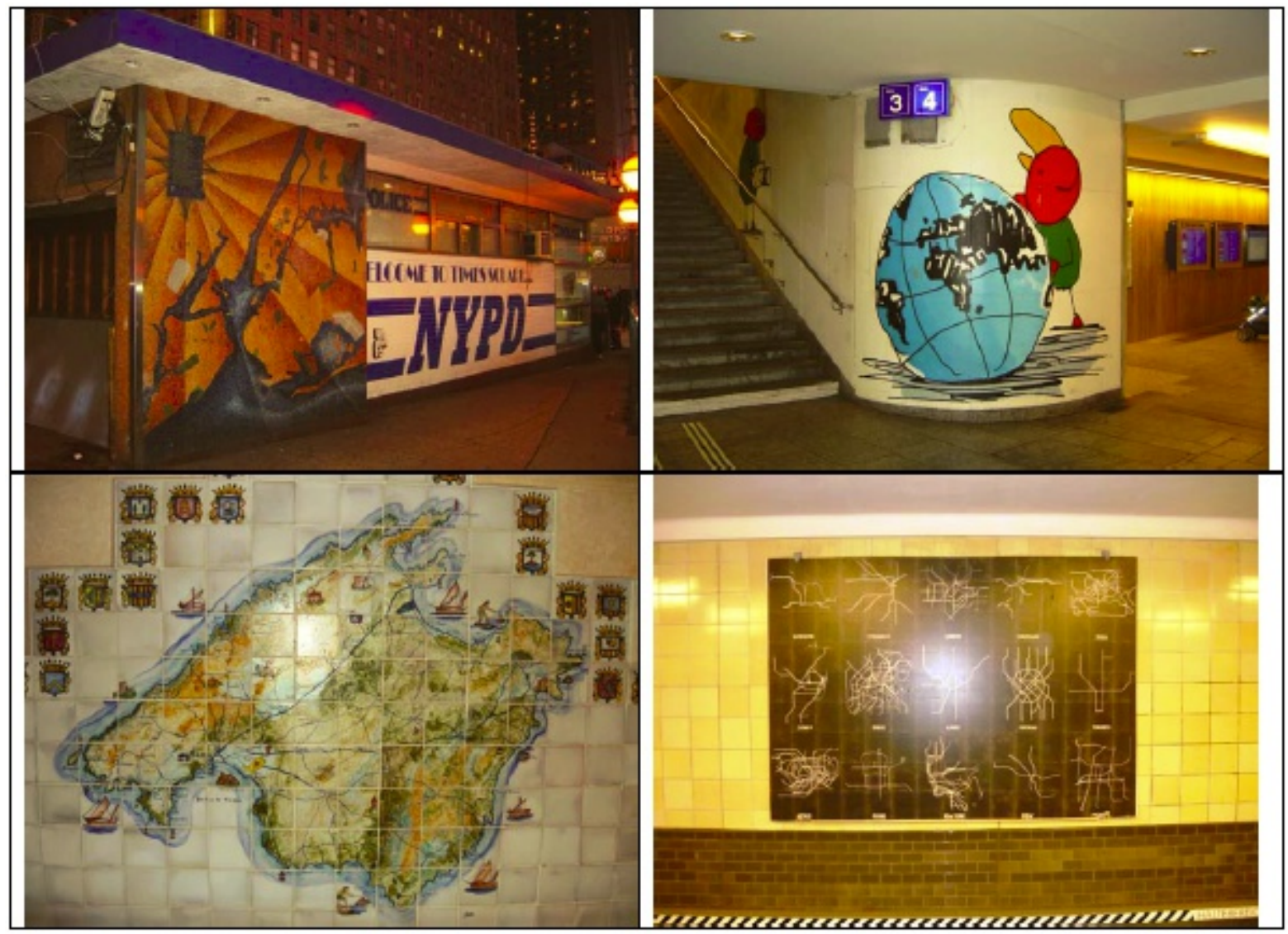

Figura 11 (Imagem $1.3 \mathrm{c}$ )

Figura 12 (Imagem $1.3 \mathrm{~d}$ )

ESPAÇO E CULTURA, UERJ, RJ, N. 36, P.35-60, JUL./DEZ. DE 2014

http://www.e-publicacoes.uerj.br/index.php/espacoecultura/ 
quase inevitável para os turistas.

Finalmente, a imagem 1.3 b (Figura 10) é o desenho de um globo terrestre com uma criança se apoiando sobre ele; pintado em uma estação de trem na cidade de Berna, ilustra a pequenez do mundo (ou, mais especificamente, o encurtamento de distâncias) proporcionada por uma rede ferroviária de última geração; a imagem 1.3 c (Figura 11), armada em uma das paredes do pequeno aeroporto de Palma de Mallorca, recebe os passageiros que ali aterrissam com um bonito mapa da ilha.

Para além das técnicas e materiais utilizados nestas produções, uma peculiaridade que compartilham os exemplos dessa série é que estão localizadas em espaços públicos, em vias de circulação. Essa localização prefigura certas tendências nos modos de observação possíveis: tratando-se de lugares de trânsito e de espera, de visita e de turismo, o olhar do transeunte pode ser entre espontâneo e distraído, entre entediado, curioso e cativo pela situação de espera. A espacialidade das imagens, por sua vez, faz parte do sentido que constrói, e quando olhamos os objetos cartografados nessas imagens não podemos ignorar os lugares que lhes dão formas de visualização próprias e específicas: "os lugares (sempre são múltiplos, devem formar uma série precisamente ordenada, são a base do sistema) são como caixas vazias, invariantes, marcos, receptáculos. São superfícies intocadas, suscetíveis para receber as imagens, por sua parte, plenas (de sentido), mas transitórias, mutáveis, que ali estão enquadradas, inscritas e depositadas, mas somente por um determinado tempo. In loco, formam a estrutura do dispositivo da memória" (DUBOIS, 2008: 277). Nos contextos aqui apresentados, os componentes estético e monumental apostam de forma decisiva para chamar atenção de um público que se encontra aleatoriamente com essas imagens, sem tê-las buscado.

\section{Série 2.1 Mapas da América do Sul}

A série 2.1 (Figuras 13, 14, 15, 16) apresenta objetos diferentes: um desenho, uma fonte d'água em uma praça pública, uma instalação artística armada no que parece ser um dormitório privado e um mapa político como os que poderíamos encontrar num atlas. 0 denominador comum é a silhueta da América do Sul, ainda que com variações notáveis. A série nos induz a comparar técnicas e formas de intervenção, mas ao mesmo tempo nos convoca a reconhecer o objeto "Sul da América" em todas elas, para além de suas radicais diferenças de estilo e materialidade.

A imagem 2.1 a (Figura 13) é o icônico mapa que o artista uruguaio Joaquim Torres Garcia criou, em várias versões, nos anos de 1930 e que foi ressignificado como um emblema da resistência dos povos do Sul sobre a imposição de padrões sociais, culturais e estéticos por parte dos do Norte. A subversão da posição do mapa é uma via para impugnar a ordem intrínseca à convenção moderna de localizar o norte na parte superior do mapa e, assim, dar prioridade a espaços percebidos como atrasados e subjugados.

Já em 1929, a ordem mundial 
havia sido criticada pelos artistas a partir do redesenho da imagem cartográfica: os surrealistas criaram um mundo diferente em um planisfério ${ }^{16}$, em que alguns países têm territórios descomunalmente extensos, enquanto outros simplesmente foram apagados do mapa; a linha do Equador está inquietantemente ondulada, e o continente europeu aparece "mutilado e reescrito" (DE DIEGO OTERO, 2008: 12).
Parece que estar "contra o mapa"17 é estar contra a ordem".

A imagem 2.1 b (Figura 14) é uma fonte d'água localizada em uma praça na cidade de Santa Fé (Argentina), em frente ao Convento de São Francisco, com o contorno do Sul da América. 0 peculiar desta fonte é que as partes de terra deveriam estar cobertas de água (se a fonte estivesse cheia) e que as

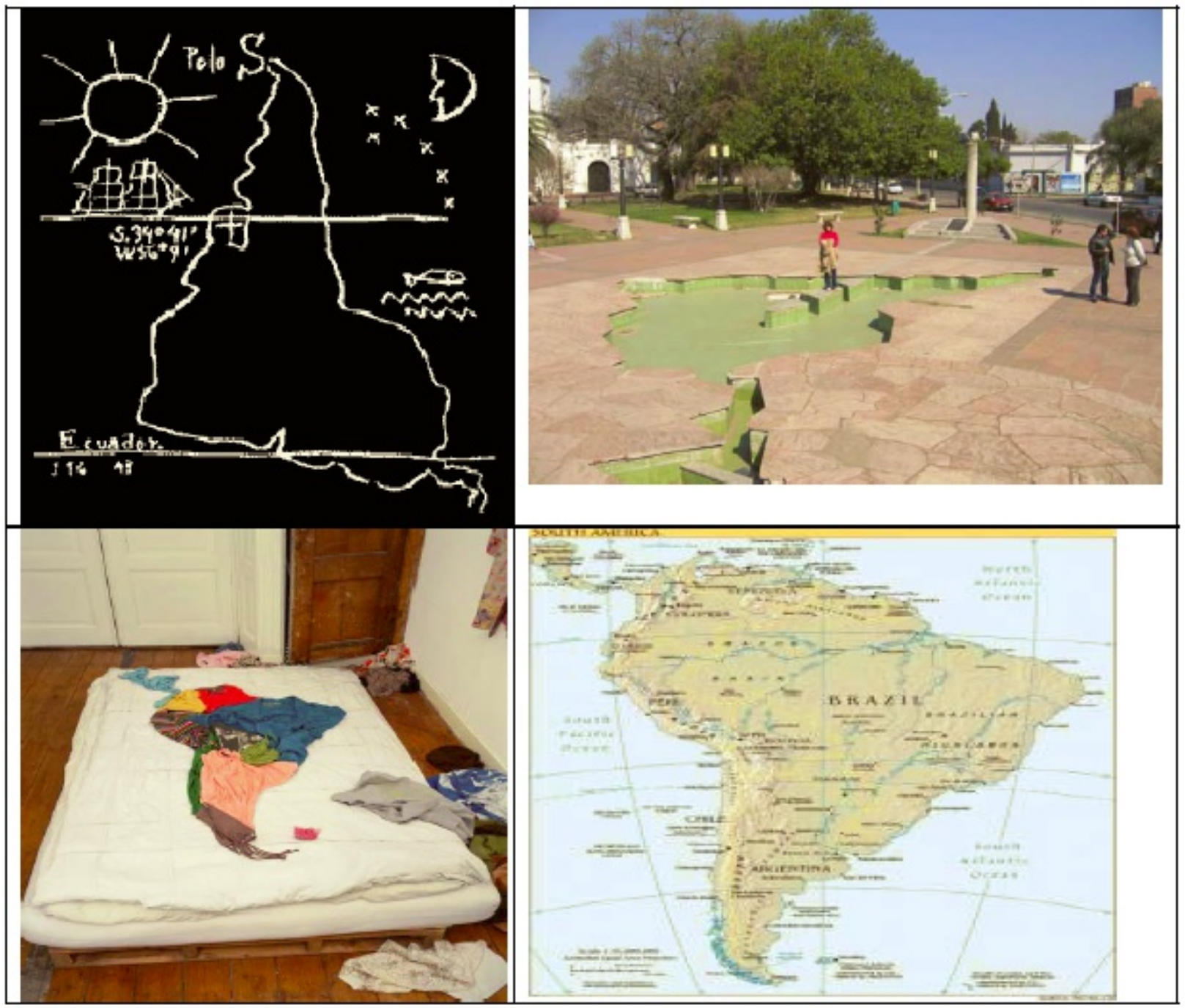

Figura 15 (Imagem 2.1 c)

Figura 16 (Imagem 2.1 d) 
partes de água estão cobertas com cimento (como os oceanos laterais e o Rio Paraná). Ou seja, aqui também se opera uma inversão das convenções cartográficas.

A imagem 2.1 c (Figura 15) é uma intervenção desenhada pelo artista russo Vlad Gerasimov ${ }^{18}$ que utiliza peças de roupa para configurar o mapa do Sul da América (cabe esclarecer que existem outros trabalhos em que é utilizada a mesma técnica para formar os mapas de outros continentes, como veremos na série seguinte). Um ambiente que tem vários vestígios do que seria uma atmosfera íntima é recriado: é um quarto fechado, tem um colchão que sugere que se trata de um dormitório e existem roupas e sapatos espalhados por toda parte, como se fosse um dormitório recentemente abandonado por seus habitantes. Com essas peças do vestuário, se arma o mapa da América do Sul.

Apesar do forte viés criativo e artístico que atravessa esses três primeiros mapas da série, a imagem $2.1 \mathrm{~d}$ (Figura 16) se apresenta como um mapa político do Sul da América e reafirma a partir do "cientificismo" que a identidade da série passa por um recorte geográfico das silhuetas dos outros mapas.

O objeto "cartografado" é o que dá identidade à essa série, ainda que alguns de seus itens tenham muito potencial para participar de outras séries muito diferentes.

\section{Série 2.2 Mapas Artísticos}

Na série 2.2 (Figuras 17, 18, 19, 20) combinamos quatro imagens que poderíamos definir como "mapas artísticos", se ao menos levássemos em conta que foram elaborados por artistas.

A imagem 2.2 a (Figura 17) é outra criação do artista russo Vlad Gerasimov, agora representando a Europa. Também sobre o chão do interior de um quarto e exibindo roupas que parecem usadas, o artista monta o mapa europeu.

Quando esta instalação de Gerasimov aparece na mesma série que o mapa de Torres Garcia (agora imagem 2.2d (Figura 20)), o laço que os une não é o referente geográfico, mas sim o campo artístico como espaço de prática e legitimação das obras.

A imagem 2.2.b (Figura 18) é o mapa de Jasper Johns, Map. 0 mapa é o tema central do trabalho (anunciado inclusive no título), mas são os nomes dos estados escritos em letra de forma que nos fazem procurar um mapa. Claro que podemos identificar essa referência, pois não há nenhuma outra característica precisa (no sentido em que essa terminação adquire na cartografia).

A imagem 2.2.c (Figura 19) é um plano urbanístico do artista argentino Guillermo Kuitca que faz parte de um conjunto maior, em que Kuitca combina a estética de uma placa radiográfica com nomes fictícios e alusões à verdadeiras cidades americanas.

0 fato de que o mapa representa uma ordem predefinida e, até certo ponto, rígida, tem sido melhor percebido pelos artistas: aqueles que se sentiram chamados para trabalhar com mapas, concordaram em alterar sua posição, ativar um antagonismo. Não nos parece acidental que os artistas 
Figura 17 (imagem 2.2 a)

Figura 18 (imagem $2.2 \mathrm{~b}$ )

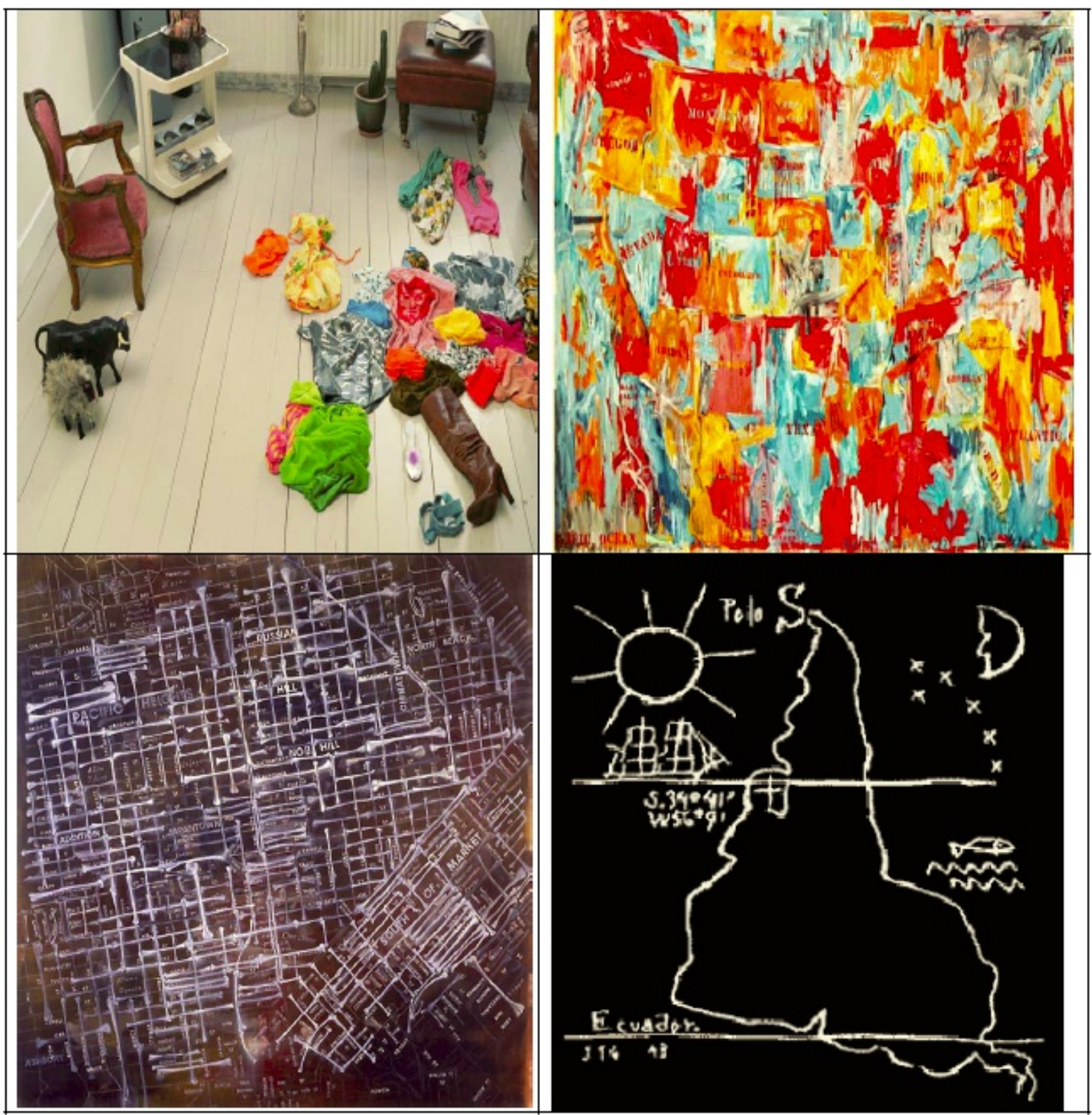

Figura 19 (imagem 2.2 c)

Figura 20 (imagem 2.2 d)

latinoamericanos, "cidadãos do hemisfério sul", concordem em inverter o mapa.

Em uma entrevista pessoal, o artista Celso Nino disse que é provável que os artistas recorram aos mapas porque "a busca de sentido, direção, localização, medidas - coisas que são ou podem ser muito exatas - é uma necessidade humana que os artistas tentam amplificar para mover ainda mais os questionamentos sobre a nossa posição no mundo, no sistema planetário, no universo. Para mim, são os mistérios das escalas, que vão desde as menores 
partículas subatômicas até o movimento das galáxias. E isto leva a um monte de indagações para todos, e os artistas tentam colocar um pouco de poesia nisso" ${ }^{19}$.

Esta série nos convida, sobretudo, a pensar quais foram os aspectos científicos que foram contestados por esses artistas.

\section{Série 2.3 Mapas do artista Guillermo Kuitca}

Dentro dos mapas artísticos, existem artistas que tem explorado especialmente a inspiração cartográfica em diversas etapas de suas obras criativas. Um deles é o célebre artista plástico argentino Guillermo Kuitca.

Figura 21 (imagem 2.3 a)

Figura 22 (imagem 2.3 b)

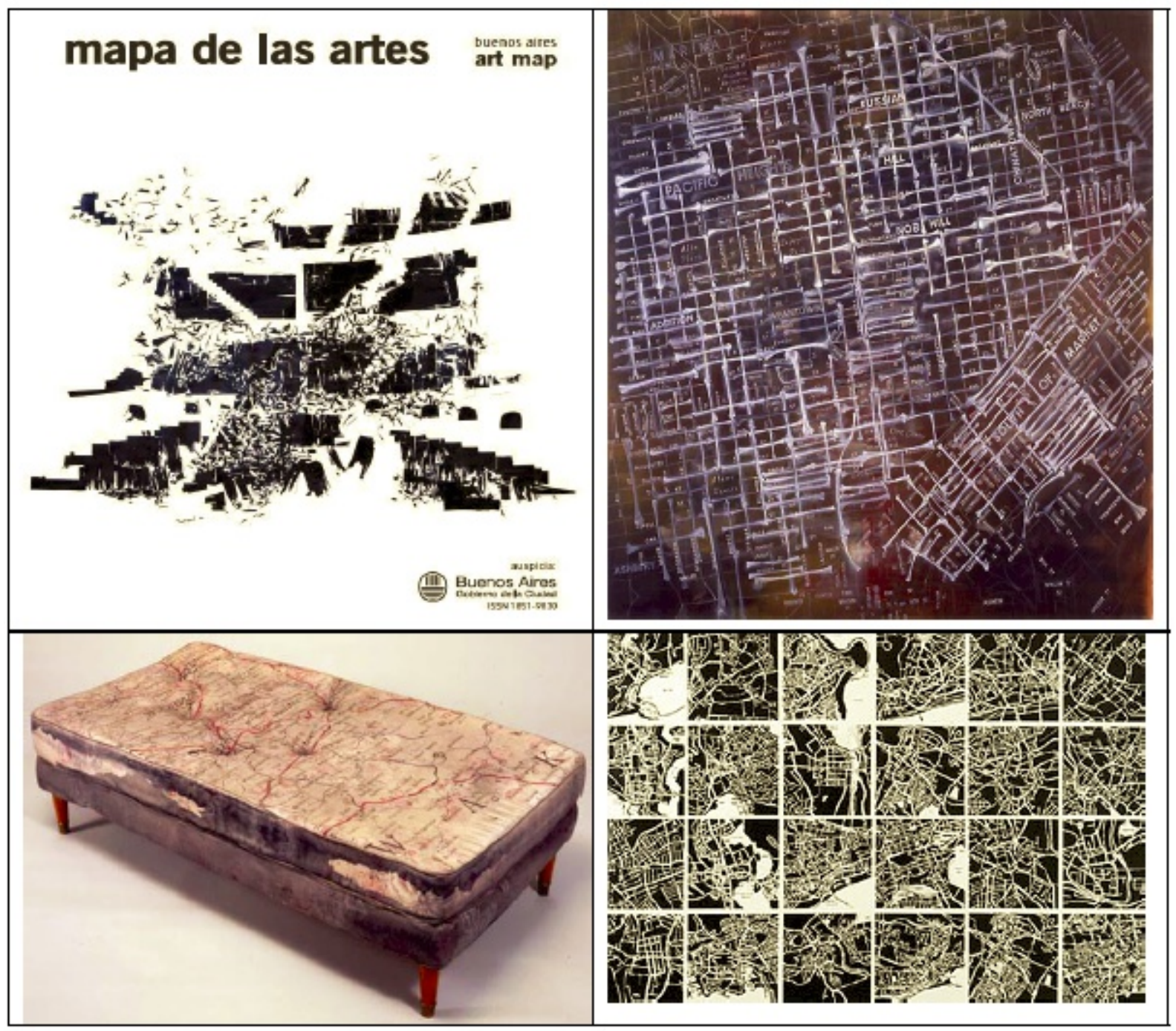

Figura 23 (imagem 2.3 c)

Figura 24 (imagem 2.3 d) 
0 mapa $2.3 \mathrm{a}^{20}$ (Figura 21) ilustra a propaganda de uma exposição do artista organizada em Buenos Aires.

A imagem 2.3.b (Figura 22) é o plano urbano incluído na série anterior. Sobre ele que o artista também compôs uma grande série com mapas que, se não são de todo fruto do imaginário, redesenham suas geografias imaginárias e transformam a linguagem cartográfica, marcas e signos que não necessariamente estão foram do contexto de sua obra.

A imagem $2.3 c^{21}$ (Figura 23) é um mapa incorporado à série "colchões" do artista, em que Kuitca executa sobre uma grande variedade de colchões: em tamanho infantil ou adulto, agrupados e isolados, com os pés de madeira ou diretamente apoiados no chão, recostados nas paredes.

A imagem 2.3 d (Figura 24) é uma colagem sem título, que monta fragmentos de planos urbanos. Estas peças deslocadas evocam a experiência pessoal de um espaço vivido que nem sempre se encaixam nas linhas desenhadas nos mapas convencionais.

Guillermo Kuitca, nestes e em outros de seus trabalhos cartográficos, explora as tensões entre a percepção e a experiência do espaço e as imagens que temos dele.

\section{Reflexões finais para discussão}

A primeira conclusão mais evidente desta análise é que a mesma imagem diz coisas diferentes em cada série. A montagem participa da construção de sentidos. Mais uma vez, as discussões de Didi-Huberman sobre a obra de Aby
Warburg destacam-se neste comentário: “o Atlas de Mnemosyne delega à montagem a capacidade de produzir, mediante encontros de imagens, um conhecimento dialético da cultura ocidental" (DIDI-HUBERMAN, 2010: 20).

0 encontro e a série transformam as imagens. Ao ler a série, somos convidados a ler mais além (e mais de perto) as imagens. Ao ler a série, estamos convidados a "ler o que nunca foi escrito" (was nie geschriben wurde, lese, nas palavras de Walter Benjamin).

Didi-Huberman afirmava que "Warburg compreendeu bem que o pensamento não é assunto de formas encontradas, sim de formas transformadas. Sujeito a migração (Wanderungen) perpétua, como ele gostava de dizer" (DIDI-HUBERMAN, 2010: 20). Aqui tentamos mudar o mesmo mapa para diversas séries para demonstrar que, em cada situação, a imagem adquire certa densidade específica. É parte da polivalência das imagens: não é só uma característica da imagem individual e de seu comportamento evasivo para evitar ser pego pela palavra. As séries configuram certos olhares e propõem itinerários.

Modestamente, pretendemos chegar a outro paralelo entre a proposta warburgiana e essas séries cartográficas. Assim como para Aby Warburg, seu objeto "é a imagem mais que a obra de arte, e isso a põe decididamente fora do capo da estética" (AGAMBEN, 2007: 162), aqui quisemos tratar os mapas que foram concebidos fora do campo da cartografia: não foram cartógrafos profissionais que os confeccionaram, 
mas sim artistas, desenhistas gráficos, jornalistas. Warburg fugiu dos princípios estéticos para pensar sobre suas imagens. Essa fuga da disciplina da estética para tratar imagens que não se encaixam tão facilmente com uma aceitação canônica do que deveria ser o tema da história da arte, torna-se relacionada com o voo da ciência cartográfica que propusemos para tratar essas imagens, sem recair em princípios científicos que são criados supostamente para dar-lhe legitimidade.

Segundo Berger, "o significado de uma imagem muda dependendo do que se vê ao lado ou imediatamente depois dela. E assim, a autoridade se mantém distribuída por todo o contexto em que aparece" (BERGER, [2000] 2013: 37). Assim, a reflexão sobre as nossas formas de organização de imagens, de montar nossos atlas/mundos e de olhar o que vemos, deve ser considerada o tópico mais ou menos invisível que lhe dá visibilidade.

$O$ mapa, no singular, não existe. $0 u$, ao menos, é indescritível. $O$ mapa são os mapas. Inclusive o mesmo mapa pode ser vários mapas. Não se trata de um jogo trapaceiro de palavras, mas sim, de resgatar a instabilidade da imagem cartográfica para demonstrar que, segundo sua posição relativa e as imagens com as quais dialoga, um mapa pode transformar a si mesmo e se converter em diversos mapas.

Nesse mesmo sentido, tentamos contribuir com algumas propostas metodológicas para abordar a pluralidade e a instabilidade da imagem cartográfica. Grande parte dessas reflexões, assim como estão inspiradas em estudos que teriam como objeto a imagem, também pretendem ser um suporte para revisitar o tratamento metodológico de fotografias, impressões, pôsteres, selos postais e vários outros tipos de imagens. 0 desafio é imenso. Mas, sem dúvida, vale a pena.

\section{Notas}

* Originalmente publicado sob o título "El mapa, los mapas. Propuestas metodológicas para abordar la pluralidad y la inestabilidad de la imagen cartográfica" em Geograficando, 11 (1), jun/2015. Traduzido por Lohanne Fernanda Ferreira (PPGEO/UERJ) e Lara Assunção (PPGEO/UERJ).

** CONICET - Universidad Nacional de La Plata -Argentina. Email: carlalois054@gmail.com

${ }^{1}$ Harley y Woodward, 1987: xvi.

${ }^{2}$ http://cartography.tuwien.ac.at/ica/ind ex.php/TheAssociation/Mission

3 "Um mapa é uma representação escalar de uma seleção de elementos ou de formas abstratas sobre (ou em relação com) à superfície terrestre ou dos corpos celestes, realizada sobre um suporte plano".

4 Soulanges, François, Estética de la fotografía. La Marca Editora. Buenos Aires: 2010. P. 114

${ }^{5}$ Este tipo de definição ainda aparece nos livros didáticos e dicionários. Tomemos como exemplo o Dicionário de Geografia editado pelo Instituto Geográfico Militar (Argentina): "Mapa: representação plana reduzida e simbolizada da superfície terrestre ou parte dela que mostra a situação e distribuição de um ou mais 
fenômenos naturais ou culturais localizáveis no espaço. Para sua confecção se levam em conta a escala e a projeção. Dependendo do fenômeno, tema ou relação de fatores a ser representado, existem diversos tipos de mapas: topográfico, geológico, batimétrico, planimétrico, meteorologia, histórico, população, corológicas, etc. "(107). PASO VIOLA, L. F. (1986). Dicionário de Geografia. Buenos Aires, Karten.

6 Harley y Woodward, (eds.)(1987)The History of Cartography. Volumen 1, Chicago - Londres, p. XVI.

7 É o termo cunhado por Benedict Anderson para se referir a silhueta cartográfica do mapa nacional e as utilizações feitas de esta silhueta em diferentes dimensões da cultura visual, com a intenção de criar consciência territorial nacionalizante: assim, "o mapa entrou numa série infinitamente reprodutível, que pode ser colocada em sinais, selos oficiais, tags, capas de revistas e livros, toalhas de mesa e paredes dos hotéis. 0 mapa-logotipo, instantaneamente reconhecido e visível por qualquer, penetrou profundamente na imaginação popular, formando um poderoso emblema dos nacionalismos que, então, nasciam" (ANDERSON, 1991: 245).

${ }^{8}$ Inclusive, é sugestivo que Jasper Johns fez uma série de objetos nacionais (entre os quais se destacam as bandeiras) ou, em outras palavras, que no campo das artes, a tematização da cartografia também implique certas conotações políticas e nacionais.

9 David Buisseret definia mapa nos seguintes termos: "O que na realidade faz com que um mapa seja um mapa é sua capacidade de representar uma situação local; talvez deveríamos chama-lo de 'imagem de situação' ou também de 'substituto situacional'. A função principal dessa imagem é transmitir informação situacional, distinguindo-a, por exemplo, de uma pintura paisagística que, ainda que transmitindo essa informação incidental, busca principalmente um efeito estético. Em termos cognitivos, o mapa deve basearse na percepção que o cérebro tem do espaço mais do que a sucessão" (2003: 16).

${ }^{10}$ Palsky, 2003.

${ }^{11}$ Nesse sentido, "a vontade discursiva do falante se realiza antes de tudo na eleição de um gênero discursivo determinado. A eleição se define pela especificidade de uma dada esfera discursiva, pelas considerações do sentido do objeto ou temática, pela situação concreta da comunicação discursiva, pela participação da comunicação, etc." (BAJTíN, 1985, 267). Tentei pela primeira vez essa proposta numa série de apresentações e artigos coletivos que preparei juntamente com Claudia Troncoso e Analía Almirón sobre a cartografia turística. Em particular, veja LOIS, TRONCOSO, ALMIRÓN, 2009.

${ }^{12}$ Citado en Didi-Huberman, 2014: 53.

13 Ver em Barrow, 2009: 354-357. ${ }^{14}$ Ver em Ovenden, 2003.

${ }^{15}$ Guide for visitors to Ise Shrine (Isem Japão) sem data, publicado entre outubro de 1948 e abril de 1954, segundo a Biblioteca de Ise Shrine, Prefeitura de Mie. Citado e reproduzido em Tufte, 1990, pp 12-13.

${ }^{16} \mathrm{O}$ mapa em questão foi publicado em 
uma página dupla (27-28) da revista belga Varietés, sob o título "Le Monde ou temps de Les Surréalistes"

17 "Contra o mapa" é o título do ensaio sugestivo da espanhola Estrella De Diego Otero, em que os mapas produzidos no campo das artes são postos em cena de modo provocador. 0 mapa dos surrealistas abre sua discussão, mas a autora costura outros mapas e outros contextos em diálogo com abordagens analíticas derivadas da proposta de Harley.

18 http://www.vladstudio.com/es/home/

19 Em entrevista pessoal do artista Celso Nino de 10 de dezembro de 2010.

${ }^{20}$ Mapa das artes. Cobertura número 31. Guillermo Kuitca. Sem título. Técnica mista sobre papel. 148 x 148 cm. 2005 .

${ }^{21}$ Guillermo Kuitca, Sem título, 1992.

\section{Bibliografía}

AGAMBEM, Giorgio (2007) La potencia del pensamiento. Buenos Aires: Adriana Hidalgo.

ANDERSON, Benedict (1991) Comunidades imaginadas. Reflexiones sobre el origen y la Difusión del nacionalismo. México: Fondo de Cultura Económica.

BAJTIN, Mijaíl (1985) Estética de la creación verbal. México: Siglo XXI.

BARROW, John (2008) Imágenes del Cosmos. Las mejores imágenes de la ciencia. Barcelona: Paidós.
BERGER, John (2013) Modos de ver. Barcelona: Gustavo Gili Editora.

BUISSERET, David (2003) La revolución cartográfica en Europa, 1400-1800. La representación de los nuevos mundos en la Europa del Renacimiento. Barcelona: Paidós.

DE DIEGO OTERO, Estrella (2005) Contra el mapa. Barcelona: Siruela.

DIDI-HUBERMAN, George 2014. Pueblos expuestos, pueblos figurantes. Buenos Airres: Manantial.

DIDI-HUBERMAN, George (2010) Atlas. ¿Cómo llevar el mundo a cuestas? Museo Nacional Centro de Arte Reina Sofía, Museum für Neue Kunst, Sammlung Falckenberg: Madrid, Karlsruhe y Hamburgo.

HARLEY, Brian \& WOODWARD, David (eds.) (1987) The History of Cartography. Volumnen 1 ChicagoLondres.

KULHAVY, Raymond W. y Stock William A. (1996) "How Cognitive Maps are Learned and Remembered", en Annals of the Association of American Geographers, Vol. 86, No. 1, Association of American Geographers, 1996, pp. 123145.

LOIS, Carla; TRONCOSO, Claudia, ALMIRÓN, Analía (2008) “Imágenes de la Argentina turística. Um análisis de la producción cartográfica de la Secretaría de Turismo de la Nación (1996-2007)”. 
En BERTONCELLO, Rodolfo. Turismo y geografía. Explorando lugares y atractivos turísticos de Argentina. Buenos Aires: Ciccus.

MITCHELL, W.J.T. (1994) Teoría de la imagen. Barcelona: AKAL Estudios Visuales (1994 [2009]). MONMONIER, Mark (1996) How to lie with maps. Chicago, The University of Chicago Press. OVENDEN, Mark (2003) Transit Maps of the World. Londres, Penguin.

PALSKY, Gilles (2003) "Cartes topographiques et cartes tematiques au XX siècle". En Ramada Curto, Diogo; Cattaneo, Angelo y Ferrand Almeida, André. La cartografía Europea tra Primo Rinascimento e fine dell'Illuminismo. Florencia, Leo S. Olschki Editore.

ROSE, Gillian (2012) Visual methodologies. An Introduction to Researching with Visual Materials. Londres: Sage.

SOULAGES, François (2010) Estética de la fotografía. Buenos Aires: La Marca Editora.

TUFTE, Edward (1990) Envisioning Information. Graphic Press.

WARBURG, Aby (2010) Atlas Mnemosyne. Madrid, AKAL. 
THE MAP, ALL MAPS. METHODOLOGICAL PROPOSALS FOR THE STUDY OF CARTOGRAPHIC IMAGE PLURALITY AND INSTABILITY

\begin{abstract}
CONSIDERING THAT "MAP" IS ALL "GRAPHIC REPRESENTATION THAT FACILITATES SPATIAL KNOWLEDGE OF THINGS, CONCEPTS, CONDITIONS, PROCESSES OR EVENTS CONCERNING THE HUMAN WORLD", THE TERM MAP REFERS TO MANY VERY DIFFERENT IMAGES, USING DIFFERENT TECHNIQUES AND MEDIA, VISUAL LANGUAGES, AND GRAPHIC CONVENTIONS THAT HAVE CHANGED OVER TIME. THIS PAPER PROPOSES TWO METHODOLOGICAL CATEGORIES TO ADDRESS THE PLURALITY OF THE CARTOGRAPHICAL IMAGE WITHOUT GIVING UP THAT BROAD AND INCLUSIVE DEFINITION. THE FIRST IS THE NOTION OF CARTOGRAPHIC GENRE, TO CLASSIFY MAPS SHARING THEMATIC, STYLISTIC, TECHNICAL OR COMPOSITIONAL KEYS. THE SECOND IS THE NOTION OF SERIES, BECAUSE THE COMPOSITION OF A SERIES CREATES INTERPRETATION KEYS AND, CONSEQUENTLY, THE SAME MAP DOES NOT COMMUNICATE THE SAME THING IN TWO DIFFERENT SERIES. THE POTENTIAL AND THE LIMITATIONS OF THESE METHODOLOGICAL PROPOSALS WILL BE DISCUSSED WITH EXAMPLES.
\end{abstract}

KEY WORDS: CARTOGRAPHIC GENRE; SERIES; METHODOLOGY; VISUAL CULTURE; MAP. 
EL MAPA, LOS MAPAS. PROPUESTAS METODOLÓGICAS PARA ABORDAR LA PLURALIDAD Y LA INESTABILIDAD DE LA IMAGEN CARTOGRÁFICA

RESUMEN: EN TANTO “MAPA” ES TODA “REPRESENTACIÓN GRÁFICA QUE FACILITA EL CONOCIMIENTO ESPACIAL DE COSAS, CONCEPTOS, CONDICIONES, PROCESOS O EVENTOS QUE CONCIERNEN AL MUNDO HUMANO", EL TÉRMINO "MAPA" REFIERE A MUCHAS IMÁGENES MUY DIFERENTES, QUE USAN DIVERSAS TÉCNICAS Y SOPORTES, APELAN A LENGUAJES VISUALES MUY HETEROGÉNEOS, CONVENCIONES GRÁFICAS QUE HAN VARIADO A LO LARGO DEL TIEMPO, ETCÉTERA. ESTE TRABAJO PROPONE DOS CATEGORÍAS METODOLÓGICAS PARA ABORDAR LA PLURALIDAD DE LA IMAGEN CARTOGRÁFICA SIN RENUNCIAR A ESA DEFINICIÓN AMPLIA E INCLUSIVA. LA PRIMERA ES LA NOCIÓN DE GÉNERO CARTOGRÁFICO, QUE PERMITE AGRUPAR Y CLASIFICAR MAPAS QUE COMPARTEN CLAVES TEMÁTICAS, ESTILÍSTICAS, TÉCNICAS Y/O COMPOSICIONALES. LA SEGUNDA ES LA NOCIÓN DE SERIE, PORQUE EL ARMADO DE UNA SERIE CREA CLAVES DE LECTURA Y DE INTERPRETACIÓN Y, CONSECUENTEMENTE, UN MISMO MAPA NO COMUNICA LO MISMO EN DOS SERIES DIFERENTES. CON EJEMPLOS SE DISCUTIRÁN LAS POTENCIALIDADES Y LAS LIMITACIONES DE ESTAS PROPUESTAS METODOLÓGICAS.

PALABRAS CLAVE: GÉNERO CARTOGRÁFICO; SERIE; METOdOLOGÍA; CULTURA VISUAL; MAPA 